\title{
Social innovation for urban liveability. Empirical evidence from the Italian third sector
}

To cite this article: Paola Garrone, Angelamaria Groppi \& Paolo Nardi (2018) Social innovation for urban liveability. Empirical evidence from the Italian third sector, Industry and Innovation, 25:6, 612-631, DOI: 10.1080/13662716.2017.1388217

Large cities are currently at the centre of important growth trajectories, but social polarization and environmental degradation impair the daily life of many city dwellers. Social innovation has emerged as a promising approach to tackle the challenge of urban liveability. Nevertheless, our understanding of the processes through which social innovations are developed and managed in critical sectors for large cities is still somewhat limited. This paper has analysed 19 case studies pertaining to third sector organizations operating in large Italian cities to find out how they produce social innovations and enhance urban liveability. The empirical results have revealed that these initiatives address some of the previously neglected needs of citizens through a flexible mode of service provision and a gradual implementation of a bundle of services. In many cases, they include a diverse base of users and involve volunteers. Enhanced accessibility and equity have been shown to be the most pervasive liveability effects.

Keywords: Social innovation, Liveable cities, Third sector.

JEL codes: O35; O18; R20 


\section{Introduction}

This paper reports the results of an empirical analysis of social innovations produced in the context of large Italian cities. ${ }^{1}$ The qualitative research presented in the paper has focused on a sample of third sector organizations (hereinafter TSOs) that provide services to the city dwellers. The aim of the paper is to contribute to the emerging debate on social innovation (hereinafter $\mathrm{SI}$ ) and urban liveability by analysing the processes that the sample TSOs have used to provide new services. Moreover, the paper also points out how TSOs deal with the challenge of urban liveability.

Large contemporary cities represent an extremely interesting case for the study of two dynamics that are central to SI research, namely social change processes and the offer of new services that address the quality of life of citizens (Edwards-Schachter and Wallace, 2017).

Today, most of the world's population lives in urban areas, making urban liveability a particularly critical issue. The problems that affect city residents are numerous, and include accessibility, equity, participation and sustainability issues (Timmer and Seymoar, 2005; see Section 2.2). Many segments of the urban population have to face issues such as unaffordable houses, and a lack of accessible green areas and sport facilities, as well as barriers to mobility for groups such as children and elderly people. This fact means that a sizeable part of the population sees its core needs unsatisfied, and is exposed to increasing marginalization and social exclusion (Gerometta et al., 2005). This is also likely to impair economic growth at a domestic and an international level, because large cities

\footnotetext{
${ }^{1}$ Large cities are defined as cities with more than 250,000 inhabitants (Dijkstra and Poelman, 2012).
} 
are nodes of knowledge, competencies and resources in a network that links the world's centres (Sassen, 1991; Mariotti, 2007).

New ideas and new approaches are needed to tackle the challenge of urban liveability. The present paper shares, with several preexisting studies, the view that $\mathrm{SI}$ is an important input, albeit not the only one, that can be considered to achieve this endeavour.

Two recent surveys, by Van der Have and Rubalcaba (2016) and Edwards-Schachter and Wallace (2017), have demonstrated that SI research is highly heterogenous, because it sums different academic communities, different objectives and different instruments, and has not yet yielded an integrated body of knowledge. In spite of this, both surveys have acknowledged that urban studies are a central strand in the field. Quite naturally, given the subject of this research, and for other reasons that will be discussed in detail in Section 2 , the definition of SI used in this paper has been taken from the influential contribution of Moulaert et al. (2005). We have assumed SI to be the satisfaction of unanswered human needs through the change of social relations and the empowerment of citizens.

However, scholars from different research communities have emphasised different elements of SI. Creativity and learning research have put greater emphasis on "methods and organizational models to generate social change" (van der Have and Rubalcaba, 2016). This paper recognises that innovative solutions are one way of coping with social challenges (Edwards-Schachter and Wallace, 2017), and focuses on the offer of new services to city residents as a typical pattern of SI development and operation.

The available inventories of $\mathrm{SI}$ practices show that $\mathrm{SI}$ is promoted by various institutional actors, such as formal and informal organizations of civil society, public authorities, business enterprises, and networks of these subjects for SI development and diffusion (for example, BEPA, 2011, and The Young Foundation, 2012). 
In this paper, we have restricted our attention to initiatives undertaken by TSOs, mainly for pragmatic reasons. The paper was originally developed as part of a wider research that investigated TSOs. ${ }^{2}$ Most notably, TSO initiatives are generally well documented by independent sources, and the thus obtained information could be used to triangulate the primary data that we collected through case studies. In addition, dealing with different types of institutional subjects would have required a far more complex conceptual framework and research design than those presented in this paper. At the same time, our focus on TSOs is not at odds with the results of preexisting research, as discussed briefly in Section 2.

The paper has two main objectives. Firstly, it aims at analysing the process through which TSOs operating in large cities develop and manage SI. The paper in particular describes how TSOs offer new services to city residents who experience one or more social challenges. Secondly, the research presented in the remaining parts of the paper has investigated the effects of SI on city dwellers, by pointing out the dimensions of urban liveability that are impacted the most by the SI developed by TSOs.

In order to pursue these research objectives, this paper presents the results of a multiple case study research, which addressed 19 initiatives developed in large Italian cities (more than 250,000 inhabitants), in the Housing, Mobility, Green areas, Shared spaces \& Heritage, Day centres and Sports activity sectors.

Several studies have analysed the determinants and effects of SI in such sectors as health, care and education (Windrum, 2013), which are obviously fundamental for the overall cohesion and sustainability of contemporary societies and economies, large cities

2 The non-profit sector, according to Salamon and Anheier (1997:61), is a domain of private, non-profitdistributing, self-governing, and at least in part voluntary organizations, and is the key institutional component of civil society. 
included. However, the problems that citizens in these sectors suffer from are not specific to large cities; they can also be observed in smaller cities and rural areas. ${ }^{3}$ This is why the empirical analysis has focused on services in infrastructural sectors that create specific challenges for city dwellers.

The case studies are mainly of a descriptive nature, because they have been used to corroborate and extend our representation of SI in urban contexts. Our efforts have been directed towards shedding light on the processes that TSOs adopt when managing new services for city dwellers, and on the impacts they have in terms of urban liveability.

The paper is organized as follows. Section 2 reviews the literature and introduces our research questions. Section 3 illustrates our research design, and offers some hints as to why large Italian cities constitute a suitable field the analysis of our research questions. The information collected through the case studies is presented in Section 4, which describes the 19 initiatives and their socially innovative content. Section 5 examines all the sample cases, and analyses the social and organizational processes activated by the sampled TSOs. Section 6 addresses the impact of the cases on the different dimensions of urban liveability. Some concluding remarks are illustrated in Section 7.

\section{Literature survey and research questions}

In this paper, we have followed the approach of Moulaert et al. (2005), who argued that SI has 'three core dimensions: the satisfaction of human needs (content dimension); changes in social relations, especially with regard to governance (process dimension); and an increase in the socio-political capability and access to resources (empowerment

\footnotetext{
${ }^{3}$ Furthermore, national regulations fix and ensure education and health service standards in many advanced countries. For instance, Italy, the country studied in the paper, despite a few criticalities, exhibits universal access to these services, in part due to the widespread presence, and an overall acceptable quality, of public sector hospitals and schools (OECD, 2015a and 2015b).
} 
dimension)'. van der Have and Rubalcaba (2016) and Edwards-Schachter and Wallace (2017) both found that this definition is the barycenter of a consistent strand of research that looks at SI as a response to social challenges which hinder local development.

The distinctive feature of the SI research conducted by local development scholars is the centrality of social change and empowerment processes, which are viewed as necessary to address the needs of households and communities. Concerns are frequently raised about the possible problems that can accompany $\mathrm{SI}$, such as the withdrawal of welfare programmes or the emergence of new inequalities and political conflicts (Brandsen et al., 2016; Larsson and Brandsen, 2016). Nevertheless, a sizeable amount of literature has associated the SI concept with new initiatives undertaken by civil society, the business sector, local governments, and cross-sectoral partnerships to cope with the problems that affect city residents and the neighbourhoods (e.g. Moulaert et al., 2005; Gerometta et al., 2005; Bouchard, 2012; Evers and Brandsen, 2016).

The definition by Moulaert et al. (2005) has been found to be appropriate for the purposes of this study, given the focus on infrastructural services in the urban context, as it points out that $\mathrm{SI}$ is accompanied by changes in social relations and a new role for citizens. Since many resources or services that are critical for urban liveability are non-excludable goods (e.g. green areas) or indivisible facilities (e.g. day centres), they cannot be provided and maintained without the coordinated actions of the users, in a similar way to the selforganized governance of common-pool resources that was the subject of Ostrom's studies (Ostrom, 1990, pp. 38-39).

Nevertheless, we recognize that another focal point of SI research is the development of new services in response to social needs (Edwards-Schachter and Wallace, 2017), and the production of "innovative solutions to socio-technical challenges or social problems" (van der Have and Rubalcaba, 2016). This field diversity does not come as a surprise, as 
the same SI concept has been 'poorly defined and demarcated' for a long time (Brandsen et al., 2016:4), and the multiplicity of definitions has resulted in a fragmented state of knowledge (van der Have and Rubalcaba, 2016).

Accordingly, the paper highlights that $\mathrm{SI}$ frequently materializes through an offer of new services. For this reason, we have found it appropriate to concentrate our empirical analysis on the development and provision of new services as a means of tackling the problems that affect city dwellers.

Finally, the paper has focused on TSOs for the practical reasons that have been illustrated in the Introduction. Moreover, several studies have pointed out the distinctive role played by TSOs in the urban domain (Evers and Laville, 2004; Moulaert et al. 2010; Bouchard, 2012) and more in general (Murray et al. 2010, p. 66; Edwards-Schachter and Wallace, 2017). The third sector has been shown to trigger new networks that promote SI (Windrum, 2013) and major public sector innovations (Pestoff, 2012:1104).

\subsection{Social and organizational processes and social innovation}

According to the survey conducted by van der Have and Rubalcaba (2016), two out of four research communities that make up SI scholarships have a clear orientation towards SI processes, namely the so-called "community psychology" and "creativity research" literature strands. The "local development" stream has a more balanced focus on process and outcomes, while the scholars that have addressed "social and societal challenges" have mainly tackled SI outcomes. Whether organizational or social, processes are central to SI research.

Several studies have investigated the social and organizational processes behind the development of new services for citizens. The most commonly cited mechanisms are 
interactive learning, users' co-creation and co-production, community participation and public engagement.

The first process through which social innovations are produced is interactive learning. Edwards-Schachter and Wallace (2017) have suggested that SI is a collective learning process, based on relations between different actors, where civil society actors play a critical role in knowledge creation. Moulaert and Hamdouch (2006) argued that learning takes place not only within organizations, but also across organizations and autonomous social actors through communication and adaptation mechanisms.

Secondly, several scholars view the co-creation and co-production of users as a distinctive element of SI (van der Have and Rubalcaba, 2016; Edwards-Schachter and Wallace, 2017). Voorberg et al. (2015) conducted a systematic review of studies that had tackled the active participation of users in the production of public services, i.e. joint involvement of public administrations and citizens. Users may be the service initiators, may participate in service design or may contribute actively to its provision, as in the case, for instance, of waste separation.

Finally, scholars that emphasise social change and empowerment as key elements of SI stress the importance of community participation and public engagement (Moulaert et al. $2005,2013)$. Although there are a few overlaps between the concept of the co-creation of users and community participation, the "local development" approach, coherently with its attention to equity outcomes, considers the participation of groups that were previously marginalized and deprived as an essential input for SI.

Almost all the abovementioned processes take place during the development phase, that is, when social innovations are conceived or created. The only possible exception is the case of users as co-implementers (Voorberg et al. 2015). Less attention has been paid to 
the social and organizational mechanisms that support the operation of new services and their provision to people on a continuing basis.

\subsection{Liveability of cities and social innovation}

The second aim of this paper has been to discover whether and how social innovations make urban contexts more liveable. Timmer and Seymoar (2005) argued that urban liveability concerns four main, inter-related pillars: accessibility, equity, participation and sustainability. They underlined that 'the quality of life experienced by citizens living in a city is tied to their ability to access infrastructure (transportation, communication, water, and sanitation); food; clean air; affordable housing; meaningful employment; and green space and parks. The differential access of people within a city to the infrastructure and amenities highlights questions of equity. The liveability of a city is also determined by the access that its residents have to participate in decision-making to meet their needs. (Timmer and Seymoar, 2005:2). On the other hand, urban unliveability means that city dwellers are affected by several intertwined risks of social polarization and exclusion, which are made worse by particular forms of environmental degradation. In other words, the liveability of cities is a 'wicked problem' (Nicholls et al., 2015:7).

There are several reasons why SI may be a means of achieving urban liveability. ${ }^{4} \mathrm{~A}$ large city may in fact be unliveable because many segments of its population have limited access to the offered resources, and consider many of their core human needs to have

\footnotetext{
${ }^{4}$ Several scholars have recently made sizeable efforts to document how social innovations cope with the challenges of contemporary cities. Gerometta et al. (2005) explored the role of civil society as the 'sphere of social organisation with the highest potential for socially innovative contributions to social integration' to counter the trends towards social exclusion in cities (Gerometta et al., 2005:2013). The WILCO (Welfare Innovations at the Local level in favour of Cohesion; http://www.wilcoproject.eu/) project is a catalogue of social innovative practices at the urban level, where specific social needs arise and are not adequately addressed by government programmes and markets (Evers and Brandsen, 2016:170-171). Social innovative policies of European cities are the subject of the ImPRovE (Poverty Reduction in Europe: Social Policy and Innovation; http://improve-research.eu/) project; several case studies have focused on a typical city issue, that is, housing (see project Work Package 11).
} 
been left unsatisfied; Moulaert et al. (2005) argued that social inclusion and equity are central to the definition of SI. The same concept of participation, one of the pillars of city liveability, overlaps two essential aspects of SI, according to Moulaert et al. (2005) i.e. changes in social relations and increases in the socio-political capability of city dwellers (Brandsen and Pestoff, 2009; Andreotti et al., 2012).

Infrastructural services that are particularly critical for urban liveability have been studied less than social or welfare services, even though social innovations have emerged in sectors that are critical for cities: housing (Bouchard, 2012), green infrastructures (Pincetl 2003), community centres, play areas and sports (Bovaird, 2007), the regeneration of abandoned buildings and places (Pares et al., 2012; Perkins, 2010), mobility and transport (EC, 2014).

Despite the fact that the relationship between SI and urban liveability is conceptually plausible, it still has not been analysed empirically in depth, through an investigation of the links between the new services offered to citizens and each dimension of urban liveability.

\subsection{Research questions}

Our first contribution to the research on $\mathrm{SI}$ in large cities is the identification of a few social and organizational dynamics that TSOs follow on a recurring basis when they run a new service for people and communities. The descriptive approach adopted for the present case studies is expected to reveal which relationship modes are activated more frequently by users and other stakeholders (e.g. volunteers, the neighbourhood, or the wider city).

While in depth investigations have been conducted in SI literature on the mechanisms activated by TSOs when they design and initiate services for people and households, less attention has been reserved to the provision processes that support the daily offer of the new service. The provision mechanisms adopted by TSOs in the operation of new 
services, and their delivery to city dwellers and communities, deserve a more detailed analysis because it is through these mechanisms that the social change and empowerment processes, which Moulaert et al. (2005) associated with SI in the urban context, unfold over time.

Our second contribution is the recognition of the liveability dimensions of a city that are influenced the most by the SI that occurs in infrastructural sectors.

Needs related to sectors such as mobility, green areas, housing and amenities, become clearly differentiated and undergo very fast changes in the urban context, especially in large cities (Weisbrod, 1998). The access to and quality of these services vary greatly across and within cities, and this aspect has been somewhat neglected in the SI literature. Limited attention has also been paid to the impacts of city liveability on individual dimensions. Nevertheless, an analytical and critical assessment of many possible influences exerted by the new services is necessary if one wants to take into due account the cautionary comments made, among others, by Brandsen et al. (2016) and Larsson and Brandsen (2016), as mentioned above. To this aim, the analysis of our case studies has taken advantage of the urban liveability challenge classification proposed by Timmer and Seymoar (2005).

The case study analysis presented in the remaining parts of the paper in particular has the aim of contributing to filling these gaps by addressing the following two research questions:

- R.1 How do those TSOs that operate in large cities develop and manage social innovations? What are the processes most commonly adopted by TSOs that offer new services to citizens?

- R.2 How do the social innovations produced by TSOs improve city liveability? What dimensions of urban liveability are impacted the most? 


\section{Empirical strategy and sample}

A multiple case study methodology has been used to learn how those TSOs that operate in large cities produce social innovations (R.1) and, as a result, have an impact on urban liveability (R.2). The research has focused on sectors that are critical for urban liveability, and which are relatively less problematic in small cities and rural areas, i.e. the local services that address those daily problems that are particularly serious in large cities.

A sample of third sector initiatives has been analysed to identify the social and organizational mechanisms through which TSOs develop and operate social innovations according to the three-fold definition provided by Moulaert et al. (2005), and to discover the most significant effects on urban households and neighbourhoods, in terms of accessibility, equity, participation and sustainability. The descriptive case studies have allowed us to understand the choices made and processes adopted by third sector providers in the investigated sectors. The case study protocol included visits to the premises of the various organizations and face-to-face interviews (lasting about 2 hours each) with personnel from these organizations (executives, and in some cases also employees, volunteers, founders, or users, for an overall total of 35 interviewees). The questionnaire was semi-structured and organized in sections: general information, governance and management, description of the provided services and users, origins and motivation, development over time, methodological choices, and relationship with public administrations and with for-profit organizations. This information was then triangulated with public documentation (from websites, blogs, media, official documents and reports). Each interview was recorded and transcribed, and the interviews were then coded to identify common themes and any distinctive aspects. 
The sample included 19 Italian third-sector cases that are located in large Italian cities and operate in the following sectors: Housing, Mobility, Green areas, Shared spaces and Heritage, Day centres for the young or disabled people, and Sports activities. In order to learn about the mechanisms that support SI (R.1), the authors concentrated on examples regarded as being successful: good practices according to the media, or to the non-profit sector and government reports, in terms of novel services as an answer to previously neglected needs; a short list was then drawn up and double-checked with sector experts. Furthemore, the value of the selected initiatives was confirmed not only by the fact that they received many public acknowledgments and prizes, but also on the basis of their capacity to spread to other Italian cities (for instance, the Portofranco and Aperti per voi cases), to increase the number of served users for all the examined cases over the years and, finally, to survive. Secondly, the authors have attempted to cover different regions and different cultural, political or social origins of organizations in the sample, in order to identify the common features on the basis of SI.

The empirical setting chosen for the case studies was Italy. ${ }^{5}$ In this way, the authors had a location advantage, as far as setting up contacts and collecting information are concerned. Italian cities also offer an appropriate test field, because they have been characterized over the years by increasing social complexity and vulnerability, which have been further exacerbated by the persistent financial crisis. Only a few data have here been given on the social and infrastructural issues that can be used to obtain an overview of the multiple and intertwined social problems that affect many inhabitants of large Italian cities (with over

\footnotetext{
${ }^{5}$ The great regional differentiation among Italian cities (mainly between Northern and Southern areas, as far as economic prosperity and social resources are concerned), has not represented a critical issue for the aims of the research, as the authors deliberately avoided focusing on path and local context dependency in the emergence of local social innovations. We would like to thank an anonymous reviewer for having pointed out this aspect.
} 
250,000 inhabitants). According to the last National Census of Italy (2011), and other official national statitics for large Italian cities (Istat 2014), over the last few years, the number of permanent full time employees has been decreasing $(57 \%$ in $2005,54 \%$ in 2013), the number of divorces and one-parent households has been rising (an increase of $74 \%$ and $26 \%$, respectively, from 2001 to 2011 ); the over 65 years' old share of the total population has increased from $18.7 \%$ in 2002 to $21.4 \%$ in 2014. In addition, in 2013, real estate prices were $90 \%$ higher than the national average in large Italian cities, whereas household income was only 15\% higher (Osservatorio Mercato Immobiliare e Servizi Estimativi, 2014). Finally, according to the 2011 National Census, the available green areas in all large Italian cities, with the exception of Rome, were well below the national average of 106 square meters per capita.

\section{Presentation of the case studies}

The final sample of case studies is shown in Table 1. Four initiatives refer to housing, 3 to mobility, 3 to green areas, 3 to shared spaces and heritage, 3 to day centres for the young or the disabled, and 3 to outdoor/indoor recreational and sporting activities. Nine initiatives are located in Milan and 2 in Turin (Northern Italy); 1 in Bologna (Central-Northern Italy); 1 in Rome (Central Italy); 2 in Catania, 2 in Naples, 1 in Bari and 1 in Palermo (Southern Italy).

The institutional forms and governance modes include cooperatives, foundations, citizens' associations and non profit enterprises. At the same time, the 19 cases shared some common traits. The organization of the aforementioned initiatives is lean in comparison with the number of served users, mainly due to the involvement of volunteers. In most cases, the service is offered free of charge; in other cases, payment is on a voluntary basis or prices are cost based. 
Table 1 here

In the following 6 sub-sections, the case studies are described briefly, mainly in terms of the provided service and targeted users, while Section 4.7 discusses whether the selected cases actually provide innovative services, as hypothesised, by verifying the first content dimension of SI, as defined by Moulaert et at. (2005) (Section 2).

\subsection{Housing sector}

The initiatives pertaining to the housing sector are relatively homogeneous. The Pompeo Leoni housing scheme (promoted by a users' cooperative that operates in university residences) is an example of good quality apartments that are offered at moderate rents to various types of users: university students, young households, single parents with children and elderly people, with the aim of promoting an effective integration between various people from Milan and outside. The Zoia houses (high energy efficiency certified) were built by a workers' cooperative (operating in the building sector) on municipally-owned land that had been granted through a tender process. The tender required that the constructed houses were purchased at a capped price, and a mix of different uses were guaranteed by renting through different pricing schemes (social and negotiated). Many additional community services have been provided by the Zoia users' cooperative: janitor, vegetable gardens, childcare centre, community centre for elderly people, daycare for children, bicycle workshop and laundry, in order to support community integration. Camplus d'Aragona, which is located in Catania (Sicily), is a historical building that has been refurbished by a Foundation that has focused on education and culture services for university students. However, it is not simply a students' residence, but is also active in supporting students during their university studies and in organizing cultural initiatives that are available to the entire city. Villaggio Barona (promoted by the local parish and a charity foundation) has been developed at a larger scale, with the aim of setting up a new 
neighbourhood in Milan. Along with social housing, which is the main service, new services have been made available to the whole neighbourhood (park, nursery school, community centre, auditorium and library), after a brown-field site had reclaimed, and welfare-related activities have been promoted and provided (for the disabled as well as for elderly people and children).

\subsection{Mobility sector}

The mobility cases are instead rather differentiated. As far as Pedibus (Milan) is concerned (initiative promoted by a non-profit association), not only do volunteers accompany children to and from school on foot, but it also involves educational activities that are carried out together with school teachers: lessons on sustainable mobility, neighbourhood history, road safety and orienteering. Carsharing Italia was the first car sharing initiative in Milan, and it was promoted by members of a leading Italian environmental non-profit association. Amicobus in Turin is a service that is offered by a non-profit association of volunteers, which transports elderly and sick people to hospitals, public offices and post offices. The service is not limited to transport, as the driver accompanies and assists the users and waits for them until the end of the visit.

\subsection{Green area sector}

Among the 3 initiatives belonging to the green area sector, Boscoincittà (promoted by an important non-profit association with the aim of preserving the cultural, artistic, historical and environmental national heritage) is a pioneering venture that has been set up to create a wood within the Milan municipality borders; the peripheral area had previously been cultivated with maize and corn crops. Nowadays, Boscoincittà hosts a multitude of activities: summer centres, team-building courses for companies, vegetable gardens, courses on botanical techniques and preserving seeds, environmental education for school kids, sports, and so on. Orti urbani Garbatella is an initiative set up by some Roman 
members of a leading Italian environmental non-profit association, which has the aim of developing and managing vegetable gardens, as a first nucleus of a future park in a dismissed area. However, there has been a slowing down of the programme as a result of a dispute with the local Municipality. Sentieri della Collina torinese is an initiative that was promoted by an Italian non-profit hiking association with the aim of clearing, maintaining, and equipping old historical and cultural trails in the hills surrounding Turin. These trails are accessible on foot or by public transport from the city centre.

\subsection{Shared spaces and heritage sector}

As far as the shared spaces and the heritage sector is concerned, two initiatives have emerged related to the clearing of urban spaces. The first, Friarielli ribelli, is an informal youth group that promotes the cleaning and reclamation of urban spaces (mainly squares) in Naples, and in some cases the planting of trees. Each initiative is preceeded by an awareness campaign through the social media web to stimulate interest in the neighbourhood, to involve volunteers, and to ensure continuity in the care of the squares. In a similar vein, Piazza Santa Maria Ausiliatrice in Catania is an urban space that has been upgraded by a spontaneous committee that spread to various neighbourhoods. The inhabitants have been involved in fund-raising and have organized festivals with the aim of making the square a part of the town. The Catania Municipality has formally granted the Committee, through a tender offer, the regular maintenance of the square and its amenities. Finally, Aperti per voi welcomes tourists and residents to buildings of artistic importance (e.g. historical mansions and churches), which would otherwise not be accessible, due to public budget constraints. The service is provided by an Italian cultural non-profit association and is operated by volunteers. 


\subsection{Day centres}

There are three daily centres pertaining to young or disabled people. Two of these cases are organizations that help high school students in their studies, thanks to the contribution of volunteers (retired teachers, other educated volunteers). The first case, the Portofranco association, which was set up in Milan, has the aim of supporting high school students through a series of services: one-to-one afternoon lessons on specific subjects, tutoring, counselling, but also conferences and other cultural and recreational events, all of which make Portofranco an authentic community centre for adolescents. The Parsifal cooperative supports junior high school students, who have dropped out of school, in a problematic neighbourhood of Palermo. The Parsifal volunteers work together with young students, not only in afternoon study groups, but also in their post-graduation careers. The third case, Ceglie del Campo, a Bari based social cooperative, has created urban vegetable gardens for disabled people in order to involve them in growing vegetables and then selling them to nearby shops.

\subsection{Sports activity sector}

Three amateur sports organizations (Centro sportivo Colombo - Milan, AD Polisportiva Europa - Naples, Polisportiva Pontevecchia- Bologna) run indoor and/or outdoor sports facilities, and are partially based on the work of volunteers in order to make sports activities more easily affordable for the young and households. Training is accompanied by leisure events for the community.

\subsection{Social innovation: content dimension}

As far as the "content dimension" is concerned, according to the definition of Moulatert et al. (2005), since they were first started, the studied initiatives have intercepted either new needs or, more frequently, previously neglected needs by designing an original answer. For instance, in 1957, when the government's priorities were focused on building houses, 
hospitals, schools, highways, etc, Polisportiva Pontevecchio identified leisure as a neglected need of households, as it was not satisfied by either public agencies or expensive and exclusive for-profit clubs. Amicobus has intercepted a new mobility demand: the need to assist and accompany elderly and sick people to hospitals or public administration offices. Pompeo Leoni has arisen from the difficulty of finding decent apartments at affordable prices for university students, a social group that is not covered by council housing and cannot cope with high market prices. Important novelty elements can also be found in Collegio Camplus d'Aragona (inclusion of education, training activities and cultural seminars, in addition to the traditional service of a students' residence), in Sentieri della Collina torinese (historical green urban trails rediscovered and restored), and in Boscoincittà (innovative idea to create a wood as an urban park). In other cases, the initiatives cannot be considered unequivocal first experiences, as they have borrowed ideas from elsewhere, but they are first-of-its-kind examples in the local context and have successfully adapted and enriched the borrowed practices to their own urban context (Carsharing Italia, Pedibus, Friarielli ribelli, Orti urbani Garbatella and Orti sociali Ceglie del Campo).

In short, these initiatives seem to act like antennas towards public administrations and other organizations, as they signal new ever-changing expectations and bridge the gap between inhabitants and authorities, thanks to their closeness to the local citizens, households and community. Moreover, a great deal of attention has been paid not only to the functional quality of the services, but also to the aesthetic quality of the facilities and premises, despite the budget constraints of most of the organizations. Camplus D'Aragona refurbished an old historical building and this action was imitated by the owners of other buildings in the same street. Prizes have been awarded to Zoia, Boscoincittà, Friarielli ribelli, and Centro sportivo Colombo because of the quality of their projects, the attention 
paid to sustainability and energy efficiency, the care of green areas, the offer of outdoor amenities, as well as the promotion of urban renewal and sanitation. It is possible to conclude that the relationship between providers and users, despite budget constraints, has fostered more attention to the quality of spaces. As Uitermark (2003) pointed out, with reference to the Dutch Restructuring Policy of disadvantaged neighbourhoods, the renewal of the housing stock (i.e., enhancing the quality of the built environment) is an appropriate way of preventing decline in these neighbourhoods. For-profit initiatives in the same sectors may instead be characterized by greater efficiency but less quality, or high quality which therefore sets these houses apart for high-income tenants.

\section{Empirical results: social innovation mechanisms}

After having discussed the social innovation content of the cases, it is worth addressing the other two social innovation dimensions identified by Moulaert et al. (2005). This section analyses the cases (Section 2) in order to identify the dynamics through which the changes in social relations and the empowerment of involved users and other stakeholders have unfolded. To this aim, the analysis highlights the most recurring operational mechanisms adopted by the analysed TSOs to deliver the new service (R.1).

Table 2 summarizes these findings, as it shows the key organizational and social mechanisms (listed in the columns) for each case that have allowed the initiatives (listed in the rows) to foster social change and empowerment, namely flexibility in service provision, volunteers' involvement, integration of diverse users, solidarity and service bundles. Each of these five features has been found to enhance either the social relations among different types of social groups, including disadvantaged and more vulnerable people (process dimension), or their socio-political capabilities and fair access to resources (empowerment dimension), and, in some cases, both of these aspects. 
First, a notable trait of the sample cases that emerges is the balance between the discretion left to the users, as far as the consumption patterns and the responsibility requested of the same users (related to the empowerment dimension) are concerned. This unusual combination gives rise to a particular kind of "flexibility of service provision". The Portofranco students, for instance, have to decide on their attendance frequency and have to personally book their lessons, thus a "top-down" approach is avoided and their sense of responsibility is strengthened. In a similar way, disabled people can rely on a job scheduling that is tailored to their specific needs at Orti sociali Ceglie del Campo. The resident members in Pompeo Leoni have to agree on co-habitation proposals.

Secondly, a notable relationship-wise dimension (i.e. volunteer involvement) has been identified in many of the initiatives, in terms of ability to involve people and to attract volunteers and to generate social networks of trust and support, which in turn leads to empowered communities, or healthy, connected and civically active communities (Scott and Liew, 2012). Portofranco is one example of this aspect. Students (often from immigrant families) are followed by volunteers (e.g. university students, or retired teachers and professional figures), and this has favoured the creation of links between teenagers, their families, Italian adults and students. One of the key factors of success is the users' perception of gratuitous support offered by a multitude of volunteers. Pedibus, Amicobus, Orti urbani Garbatella, Sentieri della Collina torinese, Friarielli ribelli, Piazza Santa Maria Ausiliatrice, Portofranco, Aperti per voi, Centro sportivo Colombo and Polisportiva Pontevecchio mainly rely on the contribution of volunteers for their service provision, while a strong propensity of the personnel to make extra efforts in many different ways has been detected in the other initiatives (for instance, in Orti sociali Ceglie del Campo, the 
operators usually help the disabled people to return home ). In some cases, the contribution of volunteers has led to a documented cost saving in the management and maintenance of the facilities (i.e., Villaggio Barona and Boscoincittà), while Amicobus may provide a better service, at a lower cost-based price, than taxi services. In Aperti per voi, the volunteers' dedication to managing local sites is a relevant aspect, because they become promoters of the local territory and heritage.

Innovative social relations may also arise from the mixing and integration of different individuals in a well-balanced equilibrium, as in the aforementioned Portofranco case (i.e. integration of diverse users). This is also the case, among others, of Orti urbani Garbatella and Polisportiva Pontevecchio, where a variety of users (unemployed, elderly people and school children) manage vegetable gardens, and people from different backgrounds attend the sports facilities, respectively. This encourages a spontaneous socialising among users and their families, with the organization of events that are open to all the inhabitants of the neighbourhood. Likewise, integration among different users is favoured in both the Pompeo Leoni and Zoia housing cases, Friarielli ribelli and Piazza Santa Maria Ausiliatrice. According to Kleinhans et al. (2007), these social interactions and networks form a special kind of "bridging" capital: cross-cutting social ties among heterogeneous individuals who help "people to 'get ahead' through access to opportunities and resources in other social circles than their own" (Kleinhans et al. 2007, p. 1074).

Furthermore, it has been found that such initiatives are made available to the whole community, as the service is not restricted to specific segments (solidarity). In this sense, Villaggio Barona is emblematic, as it was explicitly designed to include and integrate vulnerable people in an open community; different kinds of residences, services and facilities are located in the neighbourhood. Solidarity is either explicitly claimed in the organization mission (Amicobus, Parsifal, Portofranco, Orti sociali Ceglie del Campo) or 
revealed by the inclusion of weaker users (for instance, student grants in Pompeo Leoni, Campus D'Aragona, AD Polisportiva Europa). Interestingly, several authors (for instance, Kleinhans et al., 2007; Ranci, 2011) have pointed out how social capital and solidarity represent relevant dimensions of the social cohesion construct, together with other elements (common values and civic culture, social order and place attachment/identity). Finally, from a "dynamic" point of view, it is worth noting that many of these initiatives have expanded the service scope over the years through correlated services that have integrated and improved the initial offer (service bundles). For example, the portfolio of practiced sports has been expanded to include other sports initiatives over the years; Portofranco, a provider of study support, has added other services: tutoring, orienteering, counselling, organization of cultural events and conferences, as well as excursions; Boscoincittà has enriched the green park life by organizing courses, training experiences, summer centres for children from schools, firms, and households, etc; Orti sociali Ceglie del Campo, with the aim of supporting its production of vegetable gardens, has promoted six ethical purchasing groups; finally, the Zoia project has planned additional services, such as job search networking and Italian literacy courses for immigrants.

In short, according to the authors, TSOs have been found to be able to address some of the previously neglected needs of city dwellers, mainly through a flexible mode of service provision and the gradual implementation of a bundle of services. To a lesser extent, TSOs appear to include and integrate a diverse base of users and to rely to a great extent on the involvement of volunteers.

The next step of this research was the analysis of the practical effects on urban liveability, according to the definition offered in Section 2.2 (R.2). 


\section{Empirical results: impacts of social innovation on urban liveability}

The case studies have been analysed in order to understand whether third sector providers improve urban liveability through the mediation of SI. Liveability encompasses the following dimensions: accessibility, equity, participation and sustainability (Section 2.2). Within this context, it has been found that all these initiatives improve one or more aspects of city liveability (R.2), as a result of the development of social innovations, and despite their great heterogeneity. A detailed description of the liveability contribution pertaining to each case study is offered hereafter, while Table 3 summarizes the contribution of the case studies to each specific element of the liveability construct. It is worth noting how the impact on the same liveability dimension can be captured by different attributes, through which the authors have attempted to exhaust the many possibilities of expanding the liveability dimensions.

\section{Table 3 here}

First, accessibility is a core element in all the housing initiatives, but it is also typical of the services provided free of charge (i.e., Portofranco, Parsifal, Aperti per voi, Boscoincittà, Sentieri della Collina torinese). Accessibility means that the investigated initiatives increase the quantity and improve the quality of the time and spaces available to people, households and the community. Some examples of these initiatives are the suburban green land restored after years of neglect (Boscoincittà), or protected from property speculation (Orti urbani Garbatella); the opportunity to access artistic buildings and historical trails that would otherwise be closed or no longer accessible (Aperti per voi and Sentieri della Collina torinese); flexibility of the opening hours (Aperti per vol); availability of recreation and sports facilities and areas (Centro Sportivo Colombo, AD Polisportiva Europa, Polisportiva Pontevecchio); practicable paths for weaker users (Pedibus, safer 
pedestrian routes for children, and Sentieri della Collina torinese, trails that are suitable for amateur hikers and directly accessible by local public transport without needing a car to reach the starting points). For example, in Aperti per voi, artistic buildings are deliberately kept open all day to allow working people to visit during their lunch times. In other words, these initiatives are for everybody, and extend the traditional offer of services of a city, given their ability to fulfill the needs of a diversified mix of users.

In a similar way, equity has been found in all the analysed examples. Solidarity and the empowerment of users are generally used as means of pursing equity in the analysed cases. Villaggio Barona is exemplary in this sense: the inclusion of marginalized, disadvantaged and weak people is pivotal in the organization of the community. Orti sociali Ceglie del Campo is also explicitly aimed at the integration of mentally disabled people. Equity is in general enforced through the integration of a broad spectrum of players: different generations (Portofranco, Sentieri della Collina torinese, Boscoincittà, Pompeo Leoni), different cultures and ethnicities (Portofranco, Villaggio Barona), various neighbourhoods and social classes (Orti urbani Garbatella, Parsifal, Santa Maria Ausiliatrice, Friarielli ribelli, Zoia), in addition to weaker and disadvantaged people, such as the elderly and the young, the unemployed and disabled and sick people (Sentieri della Collina torinese, Amicobus, Pedibus, Orti urbani Garbatella, Villaggio Barona, Orti sociali Ceglie del Campo). For example, in the Parsifal case, not only do educators assist young students during the scholastic year, they also attend the exams to encourage them even more. This personal involvement has led to some of the mothers deciding to attend the courses, in order to obtain the leaving school certificate just like their children.

These two first elements (namely, accessibility and equity) are aimed at building a truly inclusive city, that is, one that is able to attenuate the unavoidable tensions and potential conflicts, and to address and leverage on diversity. 
As far as participation and new social relations are concerned, the residents' engagement is in some cases intrinsic to the governance arrangement (i.e. a cooperative of users, such as Pompeo Leoni and Zoia). In other cases, the residents have created associations based on a common cultural or social background (environmentalism, place attachment, solidarity, religious or political social movements), such as in the Orti urbani Garbatella, Carsharing Italia, Pedibus, Sentieri della Collina torinese, Aperti per voi, Friarielli ribelli, Piazza Santa Maria Ausiliatrice, Villaggio Barona, Portofranco, Parsifal and Orti sociali Ceglie del Campo cases, or based on common needs, e.g. in Centro sportivo Colombo, $A D$ Polisportiva Europa and Polisportiva Pontevecchio. Involvement and participation of the founders, volunteers and users have emerged as a natural consequence. For instance, in Polisportiva Pontevecchio, the parents are usually involved in many side activities (namely, as scorekeepers, tailoring sports uniforms, fund raising, organising social dinners, etc.); such activities in turn foster a profound social networking which has been found to help counterbalance both the typical conflicts of parents and children, and more important forms of social distress. In other cases, participation has resulted from the explicit participatory design of experiences, to favour social acceptance and to minimize mistrust and prejudices, by focusing on the community needs and expectations (Villaggio Barona, Zoia).

Finally, environmental sustainability has been found to be common to many experiences. The aim of conserving the landscape and of making green, equipped and accessible areas available to residents is fundamental in the green area sector cases (Boscoincittà, Orti urbani Garbatella, Sentieri della Collina torinese). In addition, efforts to educate people have emerged, and city dwellers involved in an attentive management of the whole urban environment and shared spaces have also been observed (Friarielli ribelli, Santa Maria Ausiliatrice). After the first cleaning and reclamation action performed by Friarielli ribelli in 
a square in Naples, which is usually frequented by children who play football ( the socalled "Maradona" square), the mothers in the neighborhood began to take care of the square on a daily basis. Green sustainability is naturally one of the main reasons for pursuing initiatives such as Pedibus and Carsharing Italia, but Villaggio Barona and Zoia have also paid attention to this aspect (for example, preservation of green areas against the construction of buildings, or energy efficiency certification).

In short, each of the cases examined in this paper has been found to have a beneficial impact on one or more dimensions of urban liveability, accessibility and equity in primis, and the socially innovative nature of their services has played a key role in achieving this result.

\section{Conclusions}

This paper is an attempt to contribute to the research on social innovation in large cities by focusing on a set of infrastructural sectors. The social and organizational mechanisms adopted by a sample of TSOs to provide new services to the dwellers of some large Italian cities were first analysed (R.1). It has been through the implementation of specific provision options, such as flexibility in service provision, enlargement of the service mix, diversity of involved users, reliance on volunteers and solidarity mechanisms, that the new services have been able to foster changes in social relations and empower users and other stakeholders over time. These two processes, along with the satisfying of the previously neglected needs of city dwellers, distinguish social innovation in local contexts, according to Moulaert et al. (2005). While all the provision modes have been used by one or more TSOs, the most pervasive mechanisms in the present sample are flexibility in service provision and the progressive englargement of service mixes. Our empirical findings on provision flexibility, that is, on the forms of people's choices in the use of new 
services, could be suggested as an original extension of the discussion on public service co-implementation made by Voorberg et al. (2015) to the case of TSOs. Another contribution of the paper is the empirical evidence on the evolution of service mixes, as we have strengthened Bovaird's criticism (2014) of size increase as a necessary strategy for TSOs. On the basis of our results, it is possible to state that greater attention should be paid to scope economies in social innovation as a distinctive efficiency lever.

Secondly, the paper has studied the relationship between the offer of new services and the enhancement of urban liveability (R.2). The main impacts of the studied social innovations are accessibility and equity, that is, an augmented and more equitable offer of services to the city. The quantity and quality of services have been found to increase, and formerly marginalized groups of city dwellers have become able to access services in sectors that are critical for urban life. On the other hand, the offer of new services has triggered a greater participation of users and, to a lesser extent, of communities, while better city sustainability has only been pursued in some of the examined cases. We believe that our analytical assessment of urban liveability challenges is consistent with the concerns raised by Larsson and Brandsen (2106). Although we have not investigated any cases of failure or highlighted social groups that have lost out from the implementation of the new initiatives of TSOs, we have found that the impacts of the adopted social innovation initiatives are heterogenous, and may not, at least as far as our sample is concerned, be sufficient to enhance participation and environment protection.

The external validity of these results is an open question, mainly because of the specific nature of the empirical sample. These results may not be generalizable to different sectorial and territorial contexts from the infrastructural services in large Italian cities. Moreover, the analysis has focused on TSOs, even though there may be contexts where either municipally-owned agencies or investor-owned enterprises may be more likely to 
answer the needs of people and households (Hansmann, 1996, p. 81 and pp.192-194). By and large, TSOs are also touched by other criticisms, including a lower productivity, due to the lack of "for-profit motive", poor internal accountability (Andreotti et al., 2012), limited external development (Helmig et al., 2014) and the impossibility of replacing the present welfare arrangements (Brandsen et al., 2016). A further open question concerns the ability of TSOs to undertake significant scaling-up efforts, which could expand neighbourhood and city initiatives to national or global arenas. However, there are a few cases of national and international non-profit organization networks that are already performing this task.

Although we admit that these concerns require further analysis, we are confident that the systematic description of TSO processes and impacts in a set of relatively understudied infrastructural sectors can help to enrich our comprehension and assessment of social innnovations as a way of fostering social and economic changes in large cities, in comparison with possibile alternative options.

Although the socially innovative initiatives of this sample have been found to enhance urban liveability, an extension of the case sample, in terms of number of observations and inclusion of failed cases, may be appropriate. Moreover, a comparative approach could be an intriguing development, and could permit us to learn whether more socially innovative initiatives also have a greater impact on liveability. The inclusion of other countries could also be interesting, in order to single out the influence of the institutional context; at the same time, it could be worth understanding the relevance of local path dependancy on the emergence of social innovations, as weak local conditions may produce territorial inequalities. Furthermore, issues such as the development of initiatives and economic sustainability over time, as well as an aptitude to spread the innovative practices could also be studied in depth. These topics have been left for future research. 


\section{References}

Andreotti, A., E. Mingione, and E. Polizzi. 2012. "Local Welfare Systems: A Challenge for Social Cohesion." Urban Studies 49 (9): 1925-1940. DOI:

$10.1177 / 0042098012444884$

BEPA (2011). Empowering people, driving change. Social Innovation in the European Union. Bureau of European Policy Advisers, Luxembourg: Publications Office of the European Union.

Bouchard, M. J. (2012). Social innovation, an analytical grid for understanding the social economy: the example of the Québec housing sector. Service Business, 6(1), 4759.

Bovaird, T. 2007. "Beyond Engagement and Participation: User and Community Coproduction of Public Services." Public Administration Review 67 (5): 846-860.

Bovaird, T. 2014. Efficiency in third sector partnerships for delivering local government services: the role of economies of scale, scope and learning. Public Management Review, 16(8), 1067-1090.

Brandsen, T. and V. Pestoff. 2009. "Co-production, the third sector and the delivery of public services: An introduction". In Co-production. The third sector and the delivery of public services, edited by V. Pestoff and T. Brandsen. London: Routledge.

Brandsen, T., A. Evers, S. Cattacin, and A. Zimmer (eds.). 2016. Social Innovations in the Urban Context. Nonprofit and Civil Society Studies. London: Springer. DOI 10.1007/978-3-319-21551-8_1

Cajaiba-Santana, G. (2014). Social innovation: Moving the field forward. A conceptual framework. Technological Forecasting and Social Change, 82, 42-51.

Dijkstra, L. and H. Poelman. 2012. Cities in Europe. The new OECD-EC definition. European Commission, Regional and Urban Policy. Available at http://ec.europa.eu/regional_policy/en/information/publications/regionalfocus/2012/cities-in-europe-the-new-oecd-ec-definition

Edwards-Schachter, M., and M. L. Wallace. (2017). 'Shaken, but not stirred': Sixty years of defining social innovation. Technological Forecasting and Social Change, article in press.

European Commission. 2014. Social Innovation. A decade of changes. Luxembourg: Publications Office of the European Union

Evers, A. and J.-L. Laville. 2004. The Third Sector in Europe. Cheltenham, UK: Edward Elgar Publishing

Evers, A. and T. Brandsen. 2016. "Social Innovations as Messages: Democratic Experimentation in Local Welfare Systems". In Social Innovations in the Urban Context, edited by Brandsen T. S. Cattacin, A. Evers and A. Zimmer, 161-180. London: Springer. DOI 10.1007/978-3-319-21551-8_9 
Gerometta, J., H. Haussermann, and G. Longo. 2005. "Social Innovation and Civil Society in Urban Governance: Strategies for an Inclusive City". Urban Studies 42(11): 2007-2021.

Hansmann, H. (2009). The ownership of enterprise. Cambridge, MA: Harvard University Press.

Helmig, B., S. Ingerfurth, and A. Pinz. 2014. "Success and Failure of Nonprofit Organizations: Theoretical Foundations, Empirical Evidence, and Future Research." Voluntas 25 (6): 1509-1538. DOI 10.1007/s11266-013-9402-5

ISTAT. 2014. Rapporto annuale 2014. http://www.istat.it/it/files/2014/05/Rapporto-annuale2014.pdf

Kleinhans, R., H. Priemus, and G. Engbersen. 2007. "Understanding Social Capital in Recently Restructured Urban Neighbourhoods: Two Case Studies in Rotterdam." Urban Studies 44 (5/6): 1069-1091.

Larsson, O. S., and T. Brandsen. (2016). The implicit normative assumptions of social innovation research: Embracing the dark side. In Social Innovations in the Urban Context (pp. 293-302). Springer International Publishing.

Mariotti, S. 2007. "Globalizzazione e città: le lepri del capitalismo". Stato e mercato, 27(1), 79-108.

Moulaert, F., E. Swyngedouw, F. Martinelli, and S. Gonzalez. 2005. "Towards Alternative Model(s) of Local Innovation." Urban Studies 42(11): 1969-1990.

Moulaert, F., Hamdouch, A. (2006). New views of innovation systems. Agents, rationales, networks and spatial scales in the knowledge infrastructure. Innovation, 19 (1), 11-24.

Moulaert, F. 2009. "Social Innovation: Institutionally Embedded, Territorially (Re)Produced". In Social Innovation and Territorial Development, edited by MacCallum, D., F. Moulaert, J. Hillier and S. Vicari Haddock, 11-23. Aldershot: Ashgate.

Moulaert, F., E. Swyngedouw, F. Martinelli, and S. Gonzalez. 2010. Can Neighbourhoods Save the City? Community Development and Social Innovation. London: Routledge.

Moulaert, F., D. MacCallum, A. Mehmood, and A. Hamdouch (eds). 2013. The International Handbook of Social Innovation. Cheltenham, UK: Edward Elgar Publishing

Murray, R., Caulier-Grice, J., and G. Mulgan. (2010). The open book of social innovation. Social innovator series: Ways to design, develop and grow social innovation. London: NESTA/Young Foundation.

Nicholls, A., J. Simon and M. Gabriel. 2015. "Introduction: Dimensions of Social Innovation". In New Frontiers in Social Innovation Research, edited by Nicholls, A., J. Simon and M. Gabriel, 1-26. Basingstoke: Palgrave Macmillan. DOI 10.1007/978-1-137-50680-1_1 
OECD. 2015a. Health at a Glance 2015: OECD Indicators, OECD Publishing, Paris. DOI: http://dx.doi.org/10.1787/health glance-2015-en

OECD. 2015b. Education at a Glance 2015: OECD Indicators, OECD Publishing, Paris. DOI: http://dx.doi.org/10.1787/eag-2015-en

Osservatorio Mercato Immobiliare e Servizi Estimativi - Agenzia delle Entrate. 2014. Rapporto Immobiliare 2014 - II settore residenziale. http://www.agenziaentrate.gov.it/wps/content/Nsilib/Nsi/Documentazione/omi/Pubb licazioni/Rapporti+immobiliari+residenziali/

Ostrom, E. 1990. Governing the Commons: the evolution of institutions for collective action. Cambridge: Cambridge University Press.

Pares, M., J. Bonet-Marti, and M. Marti-Costa. 2012. "Does Participation Really Matter in Urban Regeneration Policies? Exploring Governance Networks in Catalonia (Spain)." Urban Affairs Review 48: 238-271.

Perkins, H.-A. 2010. "Green Spaces of Self-Interest Within Shared Urban Governance." Geography Compass 4 (3): 255-268.

Pestoff, V. 2012. "Co-production and Third Sector Social Services in Europe: Some Concepts and Evidence." Voluntas 23 (4):1102-1118 DOI 10.1007/s11266-0129308-7.

Pincetl, S. 2003. "Nonprofits and park provision in Los Angeles: an exploration of the rise of governance approaches to the provision of local services." Social Science Quarterly 84 (4): 979-1001.

Ranci, C. 2011. "Competitiveness and Social Cohesion in Western European Cities." Urban Studies 48 (13): 2789-2804. DOI: 10.1177/0042098010394688.

Salamon, L.M. and H-K. Anheier. 1997. "The Civil Society Sector." Society, January/February: 60-65.

Sassen, S. 1991. The Global City: New York, London, Tokyo, Princeton (N.J.), Princeton University Press.

Scott, K., and T. Liew. 2012. "Social Networking as a Development Tool: A Critical Reflection." Urban Studies 49 (12): 2751-2767. DOI: $10.1177 / 0042098011435279$.

Swyngedouw, E. 2005. "Governance innovation and the citizen: The Janus face of governance-beyond-the-state." Urban Studies 42 (11): 1991-2006.

The Young Foundation (2012) Social Innovation Overview: A deliverable of the project: "The theoretical, empirical and policy foundations for building social innovation in Europe" (TEPSIE), European Commission - 7 th Framework Programme, Brussels: European Commission, DG Research

Timmer, V and N.K. Seymour. 2005. The Livable City. The World Urban Forum 2006. Vancouver Working Group Discussion Paper. International Centre for Sustainable Cities. 
van der Have, R. P. and L. Rubalcaba. (2016). Social innovation research: An emerging area of innovation studies?. Research Policy, 45(9), 1923-1935.

Voorberg, W.H., V.J.J.M. Bekkers and L.G. Tummers. 2015. "A Systematic Review of CoCreation and Co-Production: Embarking on the social innovation journey." Public Management Review 17 (9): 1333-1357. DOI:10.1080/ 14719037.2014.930505

Uitermark, J. 2003. "Social Mixing' and the Management of Disadvantaged Neighbourhoods: The Dutch Policy of Urban Restructuring Revisited." Urban Studies 40 (3): 531-549. DOI: 10.1080/0042098032000053905.

Weisbrod, B.A. 1998. The nonprofit economy. Cambridge, MA: Harvard University Press.

Windrum, P. 2013. "The co-production of health innovations". In Public-private Innovation Networks in Services, edited by Windrum, Paul, L. Rubalcaba-Bermejo, and F. Gallouj, 228-246. Cheltenham, UK: Edward Elgar Publishing

Windrum, P., L. Rubalcaba-Bermejo, and F. Gallouj. 2013. Public-private Innovation Networks in Services. Cheltenham, UK: Edward Elgar Publishing 
Table 1 - Summary of the case studies

\begin{tabular}{|c|c|c|c|c|c|}
\hline Sector & Case & $\begin{array}{l}\text { Number of } \\
\text { interviewees }\end{array}$ & City & Main service & $\begin{array}{l}\text { Institutional } \\
\text { form }\end{array}$ \\
\hline \multirow{4}{*}{ 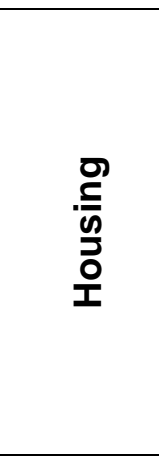 } & Pompeo Leoni & 1 & Milan & $\begin{array}{l}\text { Social housing for a mix } \\
\text { of users }\end{array}$ & Cooperative \\
\hline & Zoia & 2 & Milan & $\begin{array}{l}\text { Social housing for a mix } \\
\text { of users }\end{array}$ & Cooperative \\
\hline & $\begin{array}{l}\text { Collegio } \\
\text { Camplus } \\
\text { d'Aragona } \\
\end{array}$ & 2 & Catania & $\begin{array}{l}\text { University students' } \\
\text { residence }\end{array}$ & Foundation \\
\hline & $\begin{array}{l}\text { Villaggio } \\
\text { Barona }\end{array}$ & 3 & Milan & $\begin{array}{l}\text { Social housing for a mix } \\
\text { of users }\end{array}$ & $\begin{array}{l}\text { Foundation } \\
\text { and non-profit } \\
\text { association }\end{array}$ \\
\hline \multirow{3}{*}{$\begin{array}{l}\stackrel{Z}{ \pm} \\
\frac{\overline{0}}{0} \\
\sum\end{array}$} & Pedibus & 1 & Milan & $\begin{array}{l}\text { Accompanying children } \\
\text { to school on foot }\end{array}$ & $\begin{array}{l}\text { Non-profit } \\
\text { association }\end{array}$ \\
\hline & $\begin{array}{l}\text { Carsharing } \\
\text { Italia }\end{array}$ & 1 & Milan & Car sharing & Foundation \\
\hline & Amicobus & 1 & Turin & $\begin{array}{l}\text { Accompanying elderly } \\
\text { and sick people by car }\end{array}$ & $\begin{array}{l}\text { Non-profit } \\
\text { association }\end{array}$ \\
\hline \multirow{3}{*}{  } & Boscoincittà & 1 & Milan & $\begin{array}{l}\text { Park development and } \\
\text { management }\end{array}$ & $\begin{array}{l}\text { Non-profit } \\
\text { association }\end{array}$ \\
\hline & $\begin{array}{l}\text { Orti urbani } \\
\text { Garbatella }\end{array}$ & 1 & Rome & $\begin{array}{l}\text { Deployment of } \\
\text { vegetable gardens and } \\
\text { park }\end{array}$ & $\begin{array}{l}\text { Non-profit } \\
\text { association }\end{array}$ \\
\hline & $\begin{array}{l}\text { Sentieri della } \\
\text { Collina } \\
\text { Torinese } \\
\end{array}$ & 1 & Turin & $\begin{array}{l}\text { Clearing and operation } \\
\text { of historical trails }\end{array}$ & $\begin{array}{l}\text { Non-profit } \\
\text { association }\end{array}$ \\
\hline \multirow{3}{*}{ 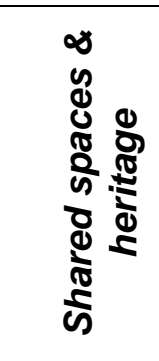 } & Friarielli ribelli & 1 & Naples & $\begin{array}{l}\text { Cleaning and } \\
\text { reclamation of green } \\
\text { areas and squares }\end{array}$ & $\begin{array}{l}\text { Informal } \\
\text { volunteers' } \\
\text { group }\end{array}$ \\
\hline & $\begin{array}{l}\text { Piazza Santa } \\
\text { Maria } \\
\text { Ausiliatrice } \\
\end{array}$ & 1 & Catania & $\begin{array}{l}\text { Revitalization and } \\
\text { management of a } \\
\text { public area }\end{array}$ & $\begin{array}{l}\text { Non-profit } \\
\text { association }\end{array}$ \\
\hline & Aperti per voi & 1 & Milan & $\begin{array}{l}\text { Welcoming visitors to } \\
\text { historical buildings }\end{array}$ & $\begin{array}{l}\text { Non-profit } \\
\text { association }\end{array}$ \\
\hline \multirow{3}{*}{ 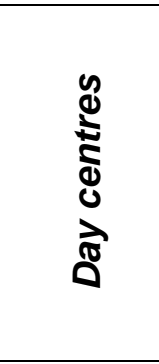 } & Portofranco & 3 & Milan & $\begin{array}{l}\text { Study support and } \\
\text { leisure for high school } \\
\text { students }\end{array}$ & $\begin{array}{l}\text { Non-profit } \\
\text { association }\end{array}$ \\
\hline & Parsifal & 6 & Palermo & $\begin{array}{l}\text { Study support for junior } \\
\text { high school students }\end{array}$ & $\begin{array}{l}\text { Social } \\
\text { cooperative }\end{array}$ \\
\hline & $\begin{array}{l}\text { Orti sociali } \\
\text { Ceglie del } \\
\text { Campo }\end{array}$ & 3 & Bari & $\begin{array}{l}\text { Gardening for disabled } \\
\text { people }\end{array}$ & $\begin{array}{l}\text { Social } \\
\text { cooperative }\end{array}$ \\
\hline \multirow{3}{*}{ 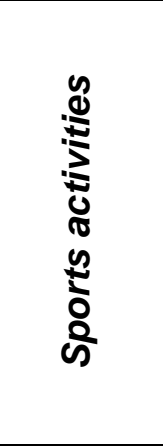 } & $\begin{array}{l}\text { Centro sportivo } \\
\text { Colombo }\end{array}$ & 2 & Milan & $\begin{array}{l}\text { Soccer school for } \\
\text { children,, young people } \\
\text { and adults }\end{array}$ & $\begin{array}{l}\text { Sports } \\
\text { association }\end{array}$ \\
\hline & $\begin{array}{l}\text { AD Polisportiva } \\
\text { Europa }\end{array}$ & 3 & Naples & $\begin{array}{l}\text { Sports courses for } \\
\text { children and young } \\
\text { people }\end{array}$ & $\begin{array}{l}\text { Sports } \\
\text { association }\end{array}$ \\
\hline & $\begin{array}{l}\text { Polisportiva } \\
\text { Pontevecchio }\end{array}$ & 1 & Bologna & $\begin{array}{l}\text { Sports and leisure } \\
\text { activities for children, } \\
\text { young people and } \\
\text { adults }\end{array}$ & $\begin{array}{l}\text { Sports } \\
\text { association }\end{array}$ \\
\hline
\end{tabular}


Table 2. The underlying social innovation mechanisms (research question 1)

\begin{tabular}{|c|c|c|c|c|c|}
\hline \multirow[b]{2}{*}{ Case } & \multicolumn{5}{|c|}{ Social innovation mechanisms (process \& empowerment dimensions) } \\
\hline & $\begin{array}{c}\text { Service provision } \\
\text { flexibility }\end{array}$ & $\begin{array}{l}\text { Volunteers' } \\
\text { involvement }\end{array}$ & $\begin{array}{l}\text { Integration of } \\
\text { diverse users }\end{array}$ & Solidarity & $\begin{array}{l}\text { Service } \\
\text { bundles }\end{array}$ \\
\hline Pompeo Leoni & + & & + & + & + \\
\hline Zoia & + & & + & + & + \\
\hline $\begin{array}{l}\text { Collegio } \\
\text { Camplus } \\
\text { d'Aragona }\end{array}$ & + & & + & + & + \\
\hline $\begin{array}{l}\text { Villaggio } \\
\text { Barona }\end{array}$ & + & + & + & + & + \\
\hline Pedibus & + & + & & & + \\
\hline $\begin{array}{l}\text { Carsharing } \\
\text { Italia }\end{array}$ & + & & & & \\
\hline Amicobus & & + & & + & + \\
\hline Boscoincittà & + & + & + & & + \\
\hline $\begin{array}{l}\text { Orti urbani } \\
\text { Garbatella }\end{array}$ & + & + & + & & + \\
\hline $\begin{array}{l}\text { Sentieri della } \\
\text { Collina } \\
\text { torinese }\end{array}$ & & + & + & & + \\
\hline Friarielli ribelli & + & + & + & & \\
\hline $\begin{array}{l}\text { Piazza Santa } \\
\text { Maria } \\
\text { Ausiliatrice }\end{array}$ & + & + & + & & + \\
\hline Aperti per voi & & + & + & & + \\
\hline Portofranco & + & + & + & + & + \\
\hline Parsifal & + & + & & + & + \\
\hline $\begin{array}{l}\text { Orti sociali } \\
\text { Ceglie del } \\
\text { Campo }\end{array}$ & + & + & & + & + \\
\hline $\begin{array}{l}\text { Centro } \\
\text { sportivo } \\
\text { Colombo }\end{array}$ & + & + & + & & + \\
\hline $\begin{array}{l}\text { AD } \\
\text { Polisportiva } \\
\text { Europa }\end{array}$ & + & + & + & & + \\
\hline $\begin{array}{l}\text { Polisportiva } \\
\text { Pontevecchio }\end{array}$ & + & + & + & & + \\
\hline
\end{tabular}


Table 3. Social innovation impact on urban liveability (research question 2)

\begin{tabular}{|c|c|c|c|c|}
\hline \multirow{2}{*}{ Case } & \multicolumn{4}{|c|}{ Urban liveability dimensions } \\
\hline & Accessibility & Equity & Participation & Sustainability \\
\hline Pompeo Leoni & ++ & + & + & \\
\hline Zoia & ++ & + & + & + \\
\hline $\begin{array}{l}\text { Collegio } \\
\text { Camplus } \\
\text { d'Aragona }\end{array}$ & ++ & + & + & \\
\hline $\begin{array}{l}\text { Villaggio } \\
\text { Barona }\end{array}$ & ++ & ++ & + & + \\
\hline Pedibus & ++ & + & + & ++ \\
\hline $\begin{array}{l}\text { Car Sharing } \\
\text { Italia }\end{array}$ & ++ & & + & ++ \\
\hline Amicobus & ++ & ++ & & \\
\hline Boscoincittà & ++ & + & + & ++ \\
\hline $\begin{array}{l}\text { Orti urbani } \\
\text { Garbatella }\end{array}$ & ++ & + & + & ++ \\
\hline $\begin{array}{l}\text { Sentieri della } \\
\text { Collina } \\
\text { torinese }\end{array}$ & ++ & + & + & ++ \\
\hline $\begin{array}{l}\text { Orti sociali } \\
\text { Ceglie del } \\
\text { Campo }\end{array}$ & ++ & + & & + \\
\hline Friarielli ribelli & ++ & + & + & + \\
\hline $\begin{array}{l}\text { Piazza Santa } \\
\text { Maria } \\
\text { Ausiliatrice }\end{array}$ & ++ & + & ++ & + \\
\hline Portofranco & ++ & ++ & + & \\
\hline Aperti per voi & ++ & & & + \\
\hline $\begin{array}{l}\text { Cooperativa } \\
\text { Parsifal }\end{array}$ & ++ & ++ & & \\
\hline $\begin{array}{l}\text { Centro } \\
\text { sportivo } \\
\text { Colombo }\end{array}$ & ++ & + & + & \\
\hline $\begin{array}{l}A D \\
\text { Polisportiva } \\
\text { Europa }\end{array}$ & ++ & ++ & + & \\
\hline $\begin{array}{l}\text { Polisportiva } \\
\text { Pontevecchio }\end{array}$ & ++ & + & ++ & \\
\hline
\end{tabular}

